\title{
Innovative Technology of Using Anti-sand Filters at Wells of the Vankor Oil and Gas Field
}

\author{
K. Vorobyev ${ }^{(\bowtie)}$ and A. Gomes \\ Department of Mineral Developing and Oil \& Gas Engineering, \\ Engineering Academy, RUDN University, Moscow, Russia \\ k.vorobyev98@mail.ru
}

\begin{abstract}
In this article, the authors considered an innovative technology for restricting sands to reduce complications and watering during the development of the Vankor gas and oil field.
\end{abstract}

Keywords: Sand control filters $\cdot$ Waterflood $\cdot$ Well $\cdot$ Borehole zone $\cdot$ Formation pressure drop

\section{Introduction}

The development of oil and gas fields in complex mining and geological conditions is associated with various complications - a drop in reservoir pressure, an increase in the water content of the crude product and the amount of mechanical impurities, destruction of the integrity of the well bottom zone. Analysis of the sources (Vorob'ev et al. 2017) shows that sand manifestations are a multifactorial and multi-element sophisticated technical system.

The task of managing the sand formation processes includes such elements as sand forecasting and effective methods of influencing the sand manifestation phases in order to reduce negative effects.

\section{Methods and Approaches}

Studies confirm that during the removal of rock particles from the reservoir in the operation of wells in the bottom zone form the high permeability channels of various widths and lengths of fractures along and bedding planes, by which the bulk of gas and produced water is filtered (Ozhogina et al. 2017).

When considering the performance of geological and technical measures at the stockwell of OJSC Gazprom (Lyashenko et al. 2018) in the direction of technology for the elimination of sand production and the removal of wells from inactivity, the causes and factors of sand production are given: poorly cemented formation; the viscosity of the formation fluid; the velocity of fluid particles in the reservoir. 


\section{Results and Discussion}

Pilot tests of filters of various designs at the Vankor oil and gas field. During 2018, pilot industrial tests of filters of various designs were carried out: slotted and multi-layer mesh.

The filter descends on an unremovable packer into the perforated interval zone and is placed opposite the entire interval in order to minimize the skin effect. The well is operated using a high-rate installation of an electric submersible pump.

At the base of a $168 \mathrm{~mm}$ column, filters with a total length of about $200 \mathrm{~m}$ are lowered into the perforation intervals. Standard filter life is 24 months. Behind the filter, another is formed - a natural filter.

The organization of the reservoir pressure maintenance system at the Vankor oil and gas field involves the use of both produced water and water from water wells.

\section{Conclusions}

According to the results of the analysis of the geological and technical conditions of water wells and the characteristics of the aquifers of the Vankor oil and gas field, it was decided to use downhole anti-sand filters to reduce the effect of removal of mechanical impurities. The results of the pilot-scale industrial tests were considered successful, which gave rise to the decision to implement filters on an industrial scale. As of January 2019, all water wells in the Vankor oil and gas field are equipped with anti-sand mesh and slot-type filters

\section{References}

Lyashenko V, Vorob'ev A, Nebohin V, Vorob'ev K (2018) Improving the efficiency of blasting operations in mines with the help of emulsion explosives. Min Mineral Deposits. 1:95-102

Ozhogina EG, Shadrunova IV, Chekushina TV (2017) Mineralogical rationale for solving environmental problems of mining regions. Gornyi zhurnal. 11:105-110

Vorob'ev A, Chekushina T, Vorob'ev K (2017) Russian national technological initiative in the sphere of mineral resource usage. Rudarsko Geolosko Naftni Zbornik. 2:1-8

Open Access This chapter is licensed under the terms of the Creative Commons Attribution 4.0 International License (http://creativecommons.org/licenses/by/4.0/), which permits use, sharing, adaptation, distribution and reproduction in any medium or format, as long as you give appropriate credit to the original author(s) and the source, provide a link to the Creative Commons license and indicate if changes were made.

The images or other third party material in this chapter are included in the chapter's Creative Commons license, unless indicated otherwise in a credit line to the material. If material is not included in the chapter's Creative Commons license and your intended use is not permitted by statutory regulation or exceeds the permitted use, you will need to obtain permission directly from the copyright holder.

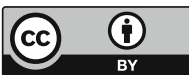

